\title{
Participation of European citizens in the EU legislative procedure
}

\section{Assya Kavrakova ${ }^{1}$}

Accepted: 7 June 2021 / Published online: 23 June 2021

(c) @ ERA 2021

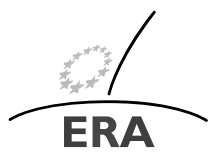

EUROPÄISCHE RECHTSAKADEMIE ACADEMY OF EUROPEAN LAW ACADEMIE DE DROIT EUROPEEN ACCADEMIA DI DIRITTO EUROPEO TRIER - TREVES - TREVIRI

\begin{abstract}
European citizens need their own permanent participatory mechanisms in the legislative procedure to exploit the full potential of citizens' participation to strengthen EU democratic legitimacy.

The European Citizens' Initiative is a unique transnational tool for participatory democracy, but it is an agenda setting instrument, challenging to use and with limited legislative impact. EU consultations and other potential channels for citizens' input, such as the REFIT Platform for Better Regulation, are too technical to ensure citizens' participation.
\end{abstract}

The Conference on the Future of Europe represents an opportunity to pilot innovative methods of citizen engagement, sustainable into the future.

Keywords EU citizens · Participation · Engagement · Co-decision · Policy-making · Crowdsourcing

\section{Introduction}

The Maastricht Treaty $1992^{1}$ established citizenship of the European Union, which supplements the national citizenship of all those who are nationals of a Member State of the European Union (Article 8).

\footnotetext{
${ }^{1}$ Treaty on European Union https://europa.eu/european-union/sites/europaeu/files/docs/body/treaty_on_ european_union_en.pdf [50].
}

A. Kavrakova

assya.kavrakova@ecas.org

1 Executive Director, European Citizen Action Service (ECAS), Brussels, Belgium 
"Every citizen has the right to participate in the democratic life of the Union", according to Article 10(3) of the Treaty on European Union" ${ }^{2}$ (TEU) and "decisions shall be taken as openly and as closely as possible to the citizen".

In addition to the fact that citizens are represented in the decision-making process at EU level by the European Parliament (Article 10(2) TEU) which is elected directly every five years; in practice, there are two main ways in which they can participate and influence the EU legislative process:

- through the organised part of civil society - civil society organisations and their networks and platforms which represent the interests of their members and constituencies at EU level; and

- directly, the possibilities and the channels for which are much more limited and less developed.

The legal basis for both forms of participation can be found in Article 11(1-3) of the TEU, which stipulates that

1. The Institutions shall, by appropriate means, give citizens and representative associations the opportunity to make known and publicly exchange their views in all areas of Union action.

2. The Institutions shall maintain an open, transparent and regular dialogue with representative associations and civil society.

3. The European Commission shall carry out broad consultations with parties concerned in order to ensure that the Union's actions are coherent and transparent.

Traditionally, citizens' participation in the decision-making process has been primarily channelled through civil society organisations and their networks at EU level. Many of these participate in different forms of structured dialogues with DirectoratesGeneral of the European Commission; ${ }^{3}$ contribute to the consultation processes of the EC on various policy and legislative initiatives; and advocate before the European Parliament through participating in hearings or in formal or informal working groups.

Only recently, after adoption of the Lisbon Treaty, European Institutions, including the Commission, have introduced mechanisms to allow more direct involvement of individual citizens in the EU decision-making process. This is expected to culminate in the long-awaited Conference on the Future of Europe, which promises, according to Vice President Dubravka Šuica, who is in charge of the Conference on behalf of the Commission, "a new transparent debate" to bring citizens "into the heart of policy making."

In fulfilment of its obligations under Article 11(3) TEU, the Commission conducts consultations on all its future legislative acts. Although the consultations are open to contributions from both organised interests (civil society organisations and other stakeholders) and individual citizens, the most notable innovation of the Lisbon

\footnotetext{
${ }^{2}$ Consolidated version of the Treaty on European Union https://eur-lex.europa.eu/legal-content/EN/TXT/ ?uri=CELEX\%3A12012M\%2FTXT [4].

${ }^{3}$ For example, Structured Dialogue with ESIF Partners 2014-2020, https://ec.europa.eu/regional_policy/ en/policy/communication/structured-dialogue-with-partners/ [25].
} 
Treaty with regard to citizens' engagement is, without doubt, the European Citizens' Initiative.

Created as a result of the consistent efforts of many direct democracy activists and civil society organisations during the Convention on the Future of Europe (2001-2004), ${ }^{4}$ the European Citizens' Initiative is the first transnational participatory democracy tool not only in the European Union, but also world-wide.

Article 11(4) of the Lisbon Treaty stipulates that:

"not less than one million citizens who are nationals of a significant number of Member States may take the initiative of inviting the European Commission, within the framework of its powers, to submit any appropriate proposal on matters where citizens consider that a legal act of the Union is required for the purpose of implementing the Treaties".

As a follow-up, the co-legislators agreed 10 years ago, in 2011, on the Regulation on the European Citizens' Initiative, (updated in 2019), ${ }^{5}$ for which entry into force was postponed by a year - until 1 April 2012 - in order to provide sufficient time for the EU institutions, Member States and all other stakeholders, including citizens, to prepare.

\section{The European citizens' initiative}

The entry into force of the European Citizens' Initiative Regulation in 2012 was met with enthusiasm by the civil society democratic community and campaigners and was immediately followed up by a number of requests for registration of concrete European Citizens' Initiatives.

In order to launch a European Citizens' Initiative (ECI), organisers are required to go through a process, involving the following main steps ${ }^{6}$ :

- Establish a citizens' committee, comprising at least seven EU citizens, living across seven EU Member States, old enough to vote in European Parliament elections. These citizens designate a representative to speak and act on behalf of the citizens' committee vis-à-vis the Commission;

- Register the Initiative in one of the official EU languages with the Commission;

- Establish an online collection system to collect online statements of support and have this system certified by the relevant national authorities or use the system provided by the Commission, which is available free of charge.

- Launch a campaign to collect statements of support with a view to obtaining at least one million signatures in twelve months, while reaching the required thresholds in

\footnotetext{
${ }^{4}$ For more information on the Convention: https://www.europarl.europa.eu/factsheets/en/sheet/4/thetreaty-of-nice-and-the-convention-on-the-future-of-europe [30].

${ }^{5}$ Regulation (EU) $2019 / 788$ of the European Parliament and of the Council of 17 April 2019 on the European citizens' initiative https://eur-lex.europa.eu/legal-content/EN/TXT/?qid=1558082143592\&uri= CELEX:32019R0788 [45].

${ }^{6}$ More information is available at the European Citizens' Initiative Forum: https://europa.eu/citizensinitiative-forum/learn_en [12].
} 
at least seven Member States (the minimum numbers correspond to the number of the Members of the European Parliament elected in each of these Member State, multiplied by 750);

- Have the collected statements of support in each Member State verified by the national authority;

- Submit the verified statements of support to the Commission, attend a public hearing in the European Parliament and await the response of the Commission to the initiative.

The first European Citizens' Initiative registered in 2012 was Fraternite $2020^{7}$ and the first to collect one million signatures was the Right 2 Water Initiative, ${ }^{8}$ followed by One of Us, ${ }^{9}$ Stop Vivisection, ${ }^{10}$ Ban Glyphosate, ${ }^{11}$ Minority SafePack ${ }^{12}$ and End the Cage Age. ${ }^{13}$

However, soon after the entry into force of the Regulation, it became clear that the instrument is not sufficiently citizen-friendly. It is challenging to collect one million signatures in the course of twelve months across at least seven Member States, while ensuring that relevant thresholds are met. In reality, organisers, institutions and responsible stakeholders were ill-prepared to make this unique and innovative agenda setting instrument work successfully.

The first almost insurmountable challenge for newly registered Initiatives was that of having their online collection systems certified. The high cost of setting up a collection system in compliance with the security requirements was prohibitive. Few certifiers were able to undertake the certification process. Those who were able to do so charged unaffordable rates. This situation forced the Commission to "stop the clock" for ongoing initiatives, to ensure that they did not waste precious time while a solution was found for them to be able to collect statements of support online. U1timately, a solution was provided by the Commission itself - Commission servers in Luxembourg were made available to organisers free of charge - for online collection of signatures. ${ }^{14}$

A further hurdle during the early years of implementation of the ECI Regulation was the narrow interpretation by the Commission's legal services of what "falls manifestly outside the competence" of the Commission, which resulted in a refusal to register approximately $40 \%$ of submitted European citizens' initiatives. ${ }^{15}$

As formulated in an article by the author of this contribution, published at the time by EURACTIV, “three years after the entry into force of the ECI (European Citizens'

\footnotetext{
${ }^{7}$ https://www.aegee.org/fraternite-2020-europes-first-citizens-initiative/ [1].

${ }^{8}$ https://www.right2water.eu/ [46].

${ }^{9}$ https://oneofus.eu/about-us/initiative-explanation/ [35].

${ }^{10} \mathrm{http} / / /$ stopvivisection.eu/en [48].

${ }^{11}$ https://stopglyphosate.org/ [47].

12 http://www.minority-safepack.eu/ [34].

${ }^{13}$ https://www.endthecageage.eu/ [6].

${ }^{14}$ https://ec.europa.eu/commission/presscorner/detail/en/IP_12_1160 [19].

${ }^{15}$ European Citizen Action Service, https://www.democracy-international.org/sites/default/files/PDF/eci_ report_ecas_2014.pdf [10].
} 
Initiative) Regulation it seems "easier for a camel to pass through the eye of a needle" than to register an ECI". ${ }^{16}$

These and other challenges, such as lack of flexibility in terms of the commencement date of the process of collection of statements of support, varying data required from citizens to sign an Initiative in the different Member States, etc., led to a realisation first, that there was a need to set up a support infrastructure to assist organisers better prepare for the challenges of their ECI journey. Secondly, the Regulation should be revised in order to make it more citizen friendly.

In terms of support to ECI organisers, until 2018, this was provided mainly by civil society organisations through the ECI Support Centre, ${ }^{17}$ the ECI Campaign ${ }^{18}$ and the European Economic and Social Committee (EESC), which organizes the annual ECI Day. ${ }^{19}$

As for revision of the ECI Regulation: despite the fact that there had been a broad consensus among all stakeholders - civil society, EESC, the European Parliament and even the technical services of the Commission - on the need for reform, it took time to convince the political level of the Commission. The lack of action was justified on the basis that the European Citizens' Initiative instrument was still in its early years of implementation and could not yet be properly assessed.

Finally, as a result of the pressure exerted by stakeholders, including the REFIT opinion on the ECI, ${ }^{20}$ described in detail in Sect. 4, the First Vice-President of the Commission, Timmermans announced that there would be a revision of the Regulation $^{21}$ (agreed upon in 2019). The updated Regulation entered into force in January 2020.

The following amendments increased the user-friendliness and accessibility of the European Citizens' Initiative for citizens intending to launch an Initiative:

- A revised and more user-friendly timeline for organisers;

- All EU citizens can pledge support regardless of their place of residence;

- Lowering the age of support to 16 (if Member States so decide);

- Option for organisers to set up a legal entity;

- Two-stage procedure allowing organisers to revise their proposal, if necessary;

- Partial registration accepted and free translation of initiative content (including annexes) in all EU languages by the European Commission;

- Flexible start date and only two possible signature collection forms;

- One central online collection system provided by the Commission free of charge (with an option for organisers to establish their own system, for initiatives registered until the end 2022 only);

- Contact points available in each Member State to provide information and assistance free of charge to groups of organisers;

\footnotetext{
${ }^{16}$ Kavrakova, A. https://www.euractiv.com/section/trade-society/opinion/reforming-the-eci-is-vital-foreuropean-democracy/ [32].

${ }^{17}$ https://ecas.org/services/eci-support-centre/ [8].

${ }^{18}$ https://citizens-initiative.eu/help-desk/ [49].

${ }^{19}$ https://www.eesc.europa.eu/en/initiatives/european-citizens-initiative/eci-day [28].

${ }^{20} \mathrm{https} / / / \mathrm{ec}$. europa.eu/info/sites/info/files/opinion_european_citizen_initiative_final.pdf [40].

${ }^{21}$ https://ec.europa.eu/info/sites/info/files/european-citizens-initiative-factsheet-sept2017_en.pdf [17].
} 
- Six months examination period for successful initiatives, allowing for a more inclusive public hearing and more time for the Commission to consult stakeholders and analyse the Initiative.

Moreover, the Regulation envisaged the establishment of a support infrastructure for ECI organisers - the European Citizens' Forum. ${ }^{22}$ This was officially launched in 2020 (based on a pilot project in the period 2018-2019) as an interactive multilingual online platform, providing advice and information to organisers before, during and after launching and implementing an Initiative. ${ }^{23}$

Through the different sections of the Forum, citizens are able to:

- LEARN more about the European Citizens' Initiative through guidance material and webinars;

- DISCUSS the European Citizens' Initiative and their ideas for Initiatives;

- CONNECT with other citizens interested in the same EU topics and Initiatives;

- SEEK ADVICE by submitting enquires and receiving tailor-made legal, campaign and fundraising advice.

While the amendments of the ECI legislative framework have created a new stimulus for initiatives, eight of which have been registered under the updated Regulation, ${ }^{24}$ the COVID-19 health crisis has put the instrument to the test again, as organisers were neither able to campaign or collect statements of support offline.

Acknowledging this challenge, the Commission extended the twelve-month term for collection of statements of support ${ }^{25}$ for ongoing initiatives twice and the European Citizens' Initiative Forum has developed a tailored programme to assist organisers to campaign and collect statements of support online, including individualized advice, webinars, discussion threads and blog posts.

In addition to the difficulties experienced and described above, two major challenges remain for organisers.

The first is that the ECI is largely unfamiliar to EU citizens. This creates an additional burden for organisers, who are required to explain not only their cause and the reasons they are collecting statements of support, but are also obliged to explain the significance of the European Citizens' Initiative.

The second challenge remains the limited impact of successful Initiatives (those which have gathered one million statements of support), as the response of the Commission generally fails to meet organisers' expectations. ${ }^{26}$ As described in the recently published draft report on Citizens' Dialogues and Citizens' Participation in EU Decision-making (2020/2201(INI)), prepared by the Committee on Constitutional Affairs,

\footnotetext{
${ }^{22}$ https://europa.eu/citizens-initiative-forum/ [13].

${ }^{23}$ The European Citizens' Initiative Forum is operated by the European Citizen Action Service (ECAS) www.ecas.org - on behalf of and under contract with the European Commission [9].

${ }^{24}$ As of April 21, 2021.

${ }^{25} \mathrm{https} / / /$ ec.europa.eu/transparency/regdoc/rep/1/2020/EN/COM-2020-221-F1-EN-MAIN-PART-1.PDF [37].

${ }^{26} \mathrm{https} / / / \mathrm{www}$. fuen.org/en/article/Minority-SafePack-The-European-Commission-turned-its-back-onnational-minorities [31].
} 
"The ECI is an important instrument of participatory democracy. However, independent assessments on the ECI conclude that its legal and political impact has been minimal. While 76 ECIs have been registered since 2012, only six of them have reached the threshold of one million signatures and therefore have been examined by the Commission. The lack of an obligation to follow up on successful ECIs is one of the reasons for the limited effects of this instrument."27

\section{Public consultations with the European Commission}

Pursuant to Article 11(3) TEU, the European Commission conducts public consultations online on its legislative initiatives, which allow contributions by any interested party.

The Stakeholder Consultation is defined as a "formal process by which the Commission collects input and views from stakeholders about its policies" 28 and is carried out through a single access point - 'Have Your Say'. 29

In conducting consultations, the Commission is committed to four general principles - participation; openness; accountability; effectiveness; and coherence, which are implemented by applying five minimum standards: clarity; targeting; publication; consultation periods (at least 12 weeks) and feedback.

The fact that consultations are open to both organised interests and citizens creates tensions between the two and fails to maximise the potential of either.

Organised interests are often of the opinion that the questionnaires are too general for them and fail to capture their expertise to accommodate citizens' contributions.

On the other hand, as illustrated by a study undertaken by the European Citizen Action Service (ECAS), for the European Economic and Social Committee, ${ }^{30}$ citizens do not know about EU public consultations. As the consultations are often very technical with lengthy questions and available in a limited number of languages, they are not attractive to citizens' participation.

The study focused on public consultations carried out by the Commission in the period 2014-2016 identified that only $22.5 \%$ of contributions were from individual citizens, while approximately 59\% were from experts (organised interests) and approximately $17 \%$ from public authorities.

Moreover, the predominant language of the consultations in 2015-2016 was English, which is a natural barrier to wider citizen participation throughout Europe.

The study issued a number of recommendations to the Commission, aimed at increasing the user-friendliness and accessibility of the consultation mechanism for citizens, namely:

\footnotetext{
${ }^{27}$ European Parliament Committee on Constitutional Affairs: DRAFT REPORT on Citizens' dialogues and Citizens' participation in the EU decision-making, p. 8 https://www.europarl.europa.eu/doceo/ document/AFCO-PR-689799_EN.pdf [29].

${ }^{28}$ Commission staff working document, Better Regulation Guidelines, Strasbourg, 19.5.2015, Chapter VII Guidelines on Stakeholder Consultation https://eur-lex.europa.eu/legal-content/EN/TXT/HTML/?uri= CELEX:52015SC0111\&from=EN [3].

${ }^{29} \mathrm{https} / / /$ ec.europa.eu/info/law/better-regulation/have-your-say [20].

${ }^{30}$ Lironi \& Peta https://www.eesc.europa.eu/sites/default/files/files/qe-07-17-001-en-n.pdf [33].
} 
- Provide translations of consultations in more languages;

- Increase the timeframe for participation in consultations launched during the summer or holiday seasons;

- Ensure the dissemination of consultation information and questionnaires on other webpages, and not only the single access point;

- Gather more details from participants (age, gender, nationality, etc.) to monitor the representativeness of consultations;

- Make the publication of individual contributions and executive reports mandatory, with clear explanations on the impact of the contributions on EU decision-making.

These findings are largely supported by the special report of the European Court of Auditors 'Have your Say!'. This report contended that the Commission's public consultations engage citizens, but fall short of outreach activities, based on an examination of a sample of 26 public consultations carried out by the Commission between 2016 and 2018. The report put forward six concrete recommendations to improve the quality of stakeholder consultation. ${ }^{31}$

Moreover, the recommendations were supported and extended in the stakeholders' contribution to the REFIT Platform Opinion on submissions XXII.4.a by the DIHK and XXII.4.b by a citizen on Stakeholder consultation mechanisms ${ }^{32}$ (of 07/06/2017). Stakeholders have reinforced the conclusion that the "one size fits all approach" of the consultations as currently practised does not work for either organised interests or for citizens".

The opinion identified that:

"in many consultations the European Commission now reaches out to individual citizens. While this may help to bridge the gap between, on the one side, what is perceived as 'the Brussels bubble' and, on the other side, the people living in Europe, it has also led to a situation in which consultation questionnaires include questions which are only directed to individual citizens. Consequently, representative stakeholders cannot respond to these questions and do not have an opportunity to provide input on the subject of the question, which might be important to them too".

Stakeholders therefore recommend that:

"to avoid the impediment of important associations' feedback whilst not achieving the intended reach-out to citizens, we consider that two types of consultations and consequently questionnaires should be designed - where relevant - one for stakeholders and a simpler one to receive the general public's opinion".

The shortcomings of the public consultations in ensuring participation of citizens has been identified in the recently published draft report on Citizens' Dialogues and Citizens' Participation in the EU Decision-making by the AFCO Committee of the European Parliament, ${ }^{33}$ which states that "although participation is open to any in-

${ }^{31}$ European Court of Auditors, pp. 47-50, https://www.eca.europa.eu/Lists/ECADocuments/SR19_14/SR_ Public_participation_EN.pdf [27].

${ }^{32} \mathrm{https} / / /$ ec.europa.eu/info/sites/info/files/xxii4ab_on_stakeholder_consultation_mechanisms.pdf [43].

${ }^{33}$ Available at https://www.europarl.europa.eu/doceo/document/AFCO-PR-689799_EN.pdf [29]. 
dividual citizen, the Commission usually identifies a target group according to the policy concerned, so that participants are mostly organised interest groups. Furthermore, the Commission self-selects its topics for public consultations".

The report argues the need for the development of permanent participatory mechanisms for citizens as "the existing participatory instruments do not provide a very effective means for citizens to influence EU decision-making and do not exploit the full potential of citizens' participation for strengthening the democratic legitimacy of the EU".

The proposal of the Parliament echoes the position of a number of citizen-centric civil society networks, such as the European Citizen Action Service (ECAS), which requested the European Commission to divide the existing online consultations on EU policy-making into two parallel channels: one designed to better gain the views of organised interests; and one tailored to collect the insights of citizens through crowdsourcing mechanisms. ${ }^{34}$

According to ECAS, decision-makers at all levels need to complement representative democracy with collaborative elements of participatory democracy in order to reduce the gap between political elites and citizens and transform their relationship into more of a partnership, especially for the co-creation of policy.

\section{The REFIT Platform for Better regulation}

The European Commission's Regulatory Fitness and Performance Programme (REFIT) aims to ensure that "EU laws deliver on their objectives at a minimum cost for the benefit of citizens and businesses". ${ }^{35}$ The platform was established for the first time in 2015 as part of the better regulation policy of the European Commission 2014-2019. At present, it is referred to as the Fit for Future Platform ${ }^{36}$ and is chaired by the Commission's Vice-President for Inter-Institutional Relations and Foresight, Maroš Šefčovič.

The REFIT platform $2015-2019^{37}$ had the following mandate as defined by its chairman at the time, First Vice-President of the Commission, Timmermans:

"The body of EU law must remain fit for purpose, up to date and as simple as possible. To ensure this, we need to hear the views of those who really know: the citizens, the small entrepreneurs, the public administrators who are faced every day with the advantages but also sometimes the inefficiencies of our laws and the way they are implemented by Member States. The REFIT Platform

\footnotetext{
${ }^{34}$ More information is available at https:/ecas.b-cdn.net/wp-content/uploads/2021/01/ECAS-Call_ Towards-a-Citizen-Centric-EU.pdf [11].

${ }^{35} \mathrm{https}$ //ec.europa.eu/info/law/law-making-process/evaluating-and-improving-existing-laws/refitmaking-eu-law-simpler-less-costly-and-future-proof_en\#: :text=Related\%20links-,About\%20REFIT, cutting\%20red\%20tape\%2C\%20whenever\%20possible [22].

${ }^{36}$ https://ec.europa.eu/info/law/better-regulation/have-your-say-simplify [21].

${ }^{37}$ https://wayback.archive-it.org/12090/20200221163756/https://ec.europa.eu/info/law/law-makingprocess/evaluating-and-improving-existing-laws/refit-making-eu-law-simpler-and-less-costly/refitplatform_en [24].
} 
is there to collect their views, assess them and turn them into pragmatic and operational suggestions to the European Commission."

The platform structure was composed of two groups: The Stakeholder Group and the Government Group. The Stakeholder Group included representatives from different stakeholders, selected through a competitive application process, such as representatives of businesses, small and medium-sized enterprises, consumers, trade unions, environmental, health care and other citizen interests. The Government Group was comprised of experts from each Member State.

Contributions - proposals to reduce the regulatory and administrative burden of EU legislation but also proposals to improve the latter - were received through an online portal called "Lighten the Load". There were no restrictions on who can submit such contributions. Members of the Stakeholder and Government Groups could make submissions as well.

Once a proposal was submitted and assessed as eligible by the Secretariat (the European Commission), it was allocated to the policy area to which it belonged (e.g., Environment, Justice, Migration etc. $)^{38}$ and dealt with by the respective rapporteurs from the Stakeholder Group. The rapporteur(s) would propose an opinion, including recommendations for discussion by the Stakeholder Group. Representatives from the relevant DGs of the European Commission were always available to respond to questions during the discussions. Provided the opinion was adopted by consensus by the Stakeholder Group, it would be submitted to the Government Group, where the Member States would provide their respective positions thereon. The final published REFIT opinion would represent the clearly articulated opinion of both groups.

Each opinion was entitled to a response from the European Commission, elaborating if the latter intended to adopt the recommendations and act on them and the time frame for action. ${ }^{39}$

In the period 2015-2019, most of the eligible contributions received through the "Lighten the Load" website were from businesses. Businesses were better prepared in terms of advance information and knowledge to take full advantage of this opportunity, while citizens were largely unaware and had difficulties understanding the purpose of the platform, resulting in many ineligible contributions.

Nonetheless, some citizens' proposals were eligible, resulting in opinions, such as those on social security coordination; ${ }^{40}$ identity and travel documents; ${ }^{41}$ and stakeholder consultation mechanisms. ${ }^{42}$

\footnotetext{
${ }^{38}$ https://wayback.archive-it.org/12090/20200221170910/https://ec.europa.eu/info/law/law-makingprocess/evaluating-and-improving-existing-laws/refit-making-eu-law-simpler-and-less-costly/refitplatform/refit-platform-recommendations-and-other-work_en [23].

${ }^{39}$ https://wayback.archive-it.org/12090/20200221170932/https://ec.europa.eu/info/law/law-makingprocess/evaluating-and-improving-existing-laws/refit-making-eu-law-simpler-and-less-costly/refitplatform/follow-platform-recommendations-opinions_en [18].

${ }^{40}$ https://wayback.archive-it.org/12090/20200308120709/https://ec.europa.eu/info/sites/info/files/vii5a_ social_security_coordination.pdf [38].

${ }^{41}$ https://wayback.archive-it.org/12090/20200308121307/https://ec.europa.eu/info/sites/info/files/ xiii3aidentitytravel_documents.pdf [39].

${ }^{42}$ https://wayback.archive-it.org/12090/20200308121740/https://ec.europa.eu/info/sites/info/files/ xxii4ab_on_stakeholder_consultation_mechanisms.pdf [44].
} 
In addition, ECAS, as a member of the Stakeholder Group, used its right to make a submission and proposed two opinions.

The first opinion proposed revision of the European Citizens' Initiative Regulation in order to make it fit for purpose. ${ }^{43}$

The second opinion requested the European Commission to issue new, updated structured guidelines (a new Communication) to the Member States ${ }^{44}$ to "clarify grey areas" in Directive 2004/38/EC. Without hampering the Member States' margin of discretion, such a Communication should aim to:

- Overcome the loopholes in the Directive resulting in outcomes which are contrary to its purpose and which may infringe EU citizens' fundamental rights, in particular the right to health care and the right to a family life (enshrined in Articles 7 and 35 of the Charter on Fundamental Rights of the EU).

- Reinforce and further develop the guidance already provided in the Commission's 2009 Communication which has not been consistently followed.

- Reflect all CJEU judgments affecting citizens' free movement rights since 2009, which have not been codified in new legislation".

The first opinion made its way relatively smoothly through both the Stakeholder and the Government Groups and resulted in a commitment by the Commission to revise the ECI Regulation. The amended Regulation reflected 5.5 out of the 6 proposals articulated in the REFIT opinion and the updated Regulation entered into force on 1 January 2020.

The opinion on the Freedom of Movement Directive ${ }^{45}$ experienced more difficulties in obtaining a consensus. Although it was approved relatively easily by the Stakeholder Group, it met resistance from some Member States insisting that such a Communication was either unnecessary or, if necessary, it should be limited to the practices of the CJEU. Some Member States even wanted the be consulted on the text of such Guidelines, if the Commission decided to proceed.

Against this background, ECAS ${ }^{46}$ and other freedom of movement activists and civil society organisations welcomed the decision of the Commission to issue a new Communication in early 2022, as stated in the last Citizenship Report, ${ }^{47}$ released in December 2020.

While the precise content of the forthcoming Structured Guidelines to the Member States remains unknown, there are hopes that these Guidelines will not be limited only to codifying CJEU rulings on the matter, but will provide clarity on ambiguous concepts in Directive 2004/38/EC. This would limit the discretion of some Member

\footnotetext{
${ }^{43}$ https://wayback.archive-it.org/12090/20200308121646/https://ec.europa.eu/info/sites/info/files/ opinion_european_citizen_initiative_final.pdf [41].

${ }^{44}$ https://wayback.archive-it.org/12090/20200308121324/https://ec.europa.eu/info/sites/info/files/xiii-10a-social-security-coordination_en.pdf [42].

${ }^{45}$ Directive 2004/38/EC https://eur-lex.europa.eu/legal-content/EN/TXT/PDF/?uri=CELEX: 32004L0038\&from=EN [5].

${ }^{46}$ https://ecas.org/at-a-closer-look-eu-citizenship-report-2020/ [7].

${ }^{47}$ https://ec.europa.eu/info/sites/default/files/eu_citizenship_report_2020_-_empowering_citizens_and_ protecting_their_rights_en.pdf [16].
} 
States to apply narrow and sometimes discriminatory interpretations of the Directive that may negatively impact EU mobile citizens' rights.

\section{The Conference on the Future of Europe}

The Conference on the Future of Europe is organised in response to the so called "democratic deficit" in the European Union, which describes a gap between the European institutions and EU citizens. It is part of the programme of the current European Commission, as President Ursula von der Leyen has pledged a "new push for European democracy". In her opening speech at the European Parliament in July 2019, ${ }^{48}$ President von der Leyen promised that she would listen to EU citizens and hear their concerns, their hopes and their expectations through a Conference on the Future of Europe.

The idea was first floated by French President Emmanuel Macron in March 2019, ahead of the European Parliament elections. The Conference was scheduled to commence in 2020 and present results during the French Presidency of the Council of the EU, in the first half of 2022.

Unfortunately, the process was delayed due to the COVID-19 crisis and other factors. It took a long time for the three EU Institutions (the Council, the Commission and the European Parliament) to agree on the management of the Conference and its leaders. As a result, the Conference will be launched on 9 May 2021 and citizens' inputs will be collected until spring 2022, when the Conference will reach its conclusions. There are concerns that the time may prove insufficient to ensure a quality, inclusive, EU-wide and citizen-centric debate to match the ambitions announced by politicians and the expectations raised in society.

The Conference is under the authority of the three EU institutions - the Commission, the European Parliament and the Council - represented by their Presidents, acting as a joint presidency. An executive board, representing the three institutions equally, was constituted to oversee the work of the Conference, and prepare Conference plenary meetings, including citizens' input and their follow up.

At the first meeting of the Executive Board of the Conference on the Future of Europe, which took place on 24 March 2021, ${ }^{49}$ the co-chairs emphasized the unique character of the Conference as a unique opportunity to set out a common path for the future, with the three EU institutions giving citizens a direct voice on the Future of Europe for the first time. They underlined the need to be innovative in this process and recalled the objective to put citizens at the heart of deliberations.

The Conference on the Future of Europe aims to give Europeans a greater say on what the EU does and how it works for them. There are high expectations that citizens will be able to participate in deliberations on key policy issues as well as having a say on structural reforms to make the Union more democratic.

\footnotetext{
${ }^{48}$ https://ec.europa.eu/commission/presscorner/detail/pt/speech_19_4230 [36].

${ }^{49}$ Summary report of the first meeting of the Executive Board of the Conference on the Future of Europe Wednesday 24 March 2021 https://ec.europa.eu/commission/presscorner/detail/en/STATEMENT_ 21_1401 [26].
} 
At European level, the EU institutions have committed to organise European citizens' panels and specific events dedicated to young people. Each Member State can organise additional events in line with their national or institutional specificities, such as national citizens' panels or thematic gatherings bringing together different views.

The institutions have launched ${ }^{50}$ an interactive multilingual digital platform ${ }^{51}$ with information and possibilities for everyone to contribute to the following topics:

- Climate change and the environment;

- Health;

- A stronger economy, social justice and jobs;

- Digital transformation;

- Values and rights, rule of law, security;

- Migration;

- Education, culture, youth and sport;

- EU in the world;

- European democracy;

- Other ideas.

Contributions and ideas should provide guidance on the future of the EU and any recommendations will be developed into a "Report to the Joint Presidency" to be presented during the French Presidency in 2022.

There is no commitment to make the outcomes binding and it is not clear at this stage how inputs will be taken on board by decision-makers. There are mixed messages when it comes to the possibility of amending the EU Treaty. The Council, in February 2021, explicitly stated that the Conference does not fall within the scope of the Treaty. However, the European Parliament seems open to the idea, if this is what citizens want.

With high expectations for this Conference, politicians will need to deliver on the results. This may not happen immediately, considering the complexity of EU decision-making. Civil society organisations are committed to closely monitor the process and push for citizens' proposals in future advocacy efforts beyond the Conference.

An important benchmark of successful management of the process will be the feedback to citizens on the proposals to be taken on board and those which will not, and why. If this is not implemented properly by the institutions, there is a risk that the entire democratic exercise will backfire, thereby widening rather than closing the gap between the EU and its citizens.

Other processes are underway in parallel with the institutional process set out above. For example, 77 civil society groups and national networks have joined forces to organise a Civil Society Convention on the Future of Europe, ${ }^{52}$ soliciting the input of civil society into the Conference results. ECAS will lead the deliberations on

\footnotetext{
${ }^{50} \mathrm{https} / / /$ ec.europa.eu/commission/presscorner/detail/en/STATEMENT_21_1624 [15].

${ }^{51} \mathrm{https}$ ://futureu.europa.eu/?locale=en [14].

${ }^{52} \mathrm{https}$ ://civilsocietyeurope.eu/the-civil-society-convention-on-the-future-of-europe-is-ready-to-work/ \#: : text=The $\% 20$ Civil $\% 20$ Society $\% 20$ Convention $\% 20$ on $\% 20$ the $\% 20$ Conference $\% 20$ of $\% 20$ Europe $\% 20$ was,and\%20that\%20citizens'\%20proposals\%20and [2].
} 
Europe in the digital age and digital transformation through its own digital crowdsourcing platform. This platform allows for implementation of pre-set questionnaires and provides a space for exchange between participants who need to register on the platform and allows them to vote on ideas/suggestions.

In its draft report on Citizens' Dialogues and Citizens' Participation in EU Decision-making, the Committee on Constitutional Affairs emphasised that:

“the largest endeavour in citizens' participation at EU level is to be made with the Conference on the Future of Europe, which should become an opportunity to closely involve citizens in a bottom-up exercise, this being an important condition for its success. It will provide valuable experience of engaging with citizens on a large scale, from which lessons will have to be drawn in the future". 53

\section{References}

1. AEGEE-Europe: Fraternité 2020 - Europe's first citizens'. initiative. Available at: https://www.aegee. org/fraternite-2020-europes-first-citizens-initiative/

2. Civil Society Europe: The Civil Society Convention on the Future of Europe Is Ready to Work (2021). Available at: https://civilsocietyeurope.eu/the-civil-society-convention-on-the-future-of-europe-isready-to-work/\#: :text=The\%20Civil\%20Society\%20Convention\%20on $\% 20$ the $\% 20$ Conference $\% 20$ of\%20Europe $\% 20$ was, and $\% 20$ that $\% 20$ citizens $\% 27 \% 20$ proposals $\% 20$ and

3. Commission Staff Working Document: Better Regulation Guidelines (2015) COM (2015) 215 final, SWD (2015) 110 final. Available at: https://eur-lex.europa.eu/legal-content/EN/TXT/HTML/? uri=CELEX:52015SC0111\&from=EN

4. Consolidated version of the Treaty on European Union, Off. J. Eur. Union C326/01 (2012), 10(3) Available at: https://eur-lex.europa.eu/legal-content/EN/TXT/?uri=CELEX\%3A12012M\%2FTXT

5. Directive 2004/38/EC of the European Parliament and of the Council of 29 April 2004 on the right of citizens of the Union and their family members to move and reside freely within the territory of the Member States amending Regulation (EEC) No 1612/68 and repealing Directives 64/221/EEC. 68/360/EEC, 72/194/EEC, 73/148/EEC, 75/34/EEC, 75/35/EEC, 90/364/EEC, 90/365/EEC and 93/96/EEC [2004] OJ L 158/77. Available at: https://eur-lex.europa.eu/legal-content/ EN/TXT/PDF/?uri=CELEX:32004L0038\&from=EN

6. End the Cage Age: Website. Available at: https://www.endthecageage.eu/

7. European Citizen Action Service: At a closer look. EU Citizenship Report 2020, (2020). Available at: https://ecas.org/at-a-closer-look-eu-citizenship-report-2020/

8. European Citizen Action Service: ECI Support Centre. Available at: https://ecas.org/services/ecisupport-centre/

9. European Citizen Action Service: European Citizens' Initiative Forum. Available at: https://ecas.org/ services/eci-forum/

10. European Citizen Action Service: The European Citizens' Initiative Registration: Falling at the First Hurdle? (2014). Available at: https://www.democracy-international.org/sites/default/files/PDF/ eci_report_ecas_2014.pdf

11. European Citizen Action Service: Towards a Citizen Centric European Union (2020). Available at: https://ecas.b-cdn.net/wp-content/uploads/2021/01/ECAS-Call_Towards-a-Citizen-Centric-EU.pdf

12. European Citizens' Initiative Forum: Learn. Available at: https://europa.eu/citizens-initiative-forum/ learn_en

13. European Citizens' Initiative Forum: Website. Available at: https://europa.eu/citizens-initiativeforum/

${ }^{53}$ European Parliament Committee on Constitutional Affairs: DRAFT REPORT on Citizens' dialogues and Citizens' participation in the EU decision-making, pp. 7-8 https://www.europarl.europa.eu/doceo/ document/AFCO-PR-689799_EN.pdf [29]. 
14. European Commission: Conference on the Future of Europe Website. Available at: https://futureu. europa.eu/?locale=en

15. European Commission: Conference on the Future of Europe: launch of the citizens' platform on 19 April. Statement. (2021). Available at: https://ec.europa.eu/commission/presscorner/detail/en/ STATEMENT_21_1624

16. European Commission: EU Citizenship Report 2020 Empowering citizens and protecting their rights (2020). Available at: https://ec.europa.eu/info/sites/default/files/eu_citizenship_report_2020_empowering_citizens_and_protecting_their_rights_en.pdf

17. European Commission: European Citizens' Initiative. Factsheet (2017). Available at: https://ec. europa.eu/info/sites/info/files/european-citizens-initiative-factsheet-sept2017_en.pdf

18. European Commission: Follow-up of the Platform recommendations (opinions). Available at: https:// wayback.archive-it.org/12090/20200221170932/https://ec.europa.eu/info/law/law-making-process/ evaluating-and-improving-existing-laws/refit-making-eu-law-simpler-and-less-costly/refit-platform/ follow-platform-recommendations-opinions_en

19. European Commission: Green light for first European Citizens' Initiative running on Commission's own servers Press release (2012). Available at: https://ec.europa.eu/commission/presscorner/detail/en/ IP_12_1160

20. European Commission: Have your say. Available at: https://ec.europa.eu/info/law/better-regulation/ have-your-say

21. European Commission: Have your say: simplify! Available at: https://ec.europa.eu/info/law/betterregulation/have-your-say-simplify

22. European Commission: REFIT - making EU law simpler, less costly and future proof. Available at: https://ec.europa.eu/info/law/law-making-process/evaluating-and-improving-existinglaws/refit-making-eu-law-simpler-less-costly-and-future-proof_en\#: :text=Related\%20links-, About $\% 20$ REFIT,cutting\%20red\%20tape \%2C\%20whenever\%20possible

23. European Commission: REFIT Platform recommendations and other work. Available at: https:// wayback.archive-it.org/12090/20200221170910/https://ec.europa.eu/info/law/law-making-process/ evaluating-and-improving-existing-laws/refit-making-eu-law-simpler-and-less-costly/refit-platform/ refit-platform-recommendations-and-other-work_en

24. European Commission: REFIT Platform. Available at: https://wayback.archive-it.org/12090/ 20200221163756/https://ec.europa.eu/info/law/law-making-process/evaluating-and-improvingexisting-laws/refit-making-eu-law-simpler-and-less-costly/refit-platform_en

25. European Commission: Structured Dialogue with partners at Union level (2014-2020). Available at: https://ec.europa.eu/regional_policy/en/policy/communication/structured-dialogue-with-partners/

26. European Commission: Work begins on the Conference on the Future of Europe. Press release (2021). Available at: https://ec.europa.eu/commission/presscorner/detail/en/STATEMENT_21_1401

27. European Court of Auditors: 'Have your say!': Commission's public consultations engage citizens, but fall short of outreach activities (2019). Special Report, Available at: https://www.eca.europa.eu/ Lists/ECADocuments/SR19_14/SR_Public_participation_EN.pdf

28. European Economic and Social Committee ECI Day (2020). Available at: https://www.eesc.europa. eu/en/initiatives/european-citizens-initiative/eci-day

29. European Parliament Committee on Constitutional Affairs: DRAFT REPORT on Citizens' dialogues and Citizens' participation in the EU decision-making [2021] (2020/2201(INI)). Available at: https:// www.europarl.europa.eu/doceo/document/AFCO-PR-689799_EN.pdf

30. European Parliament: The Treaty of Nice and the Convention on the Future of Europe. Fact Sheet (2020). Available at: https://www.europarl.europa.eu/factsheets/en/sheet/4/the-treaty-of-niceand-the-convention-on-the-future-of-europe

31. Federal Union of European Nationalities: Minority SafePack: The European Commission turned its back on national minorities (2021). Available at: https://www.fuen.org/en/article/Minority-SafePackThe-European-Commission-turned-its-back-on-national-minorities

32. Kavrakova, A.: Reforming the ECI is vital for European democracy (2015). Available at: https://www. euractiv.com/section/trade-society/opinion/reforming-the-eci-is-vital-for-european-democracy/

33. Lironi, E., Peta, D.: EU public consultations in the digital age: enhancing the role of the EESC and civil society organisations (2017). Available at: https://www.eesc.europa.eu/sites/default/files/files/qe07-17-001-en-n.pdf

34. Minority SafePack: Website. Available at: http://www.minority-safepack.eu/

35. One of Us: Initiative Explanation. Available at: https://oneofus.eu/about-us/initiative-explanation/

36. Opening Statement in the European Parliament Plenary Session by Ursula von der Leyen Candidate for President of the European Commission 
37. Proposal for a Regulation of the European Parliament and of the Council laying down temporary measures concerning the time limits for the collection, verification and examination stages provided for in Regulation (EU) 2019/788 on the European citizens' initiative in view of the COVID-19 outbreak [2020] COM(2020) 221 final 2020/0099(COD). Available at: https://ec.europa.eu/transparency/ regdoc/rep/1/2020/EN/COM-2020-221-F1-EN-MAIN-PART-1.PDF

38. REFIT Platform: REFIT Platform Opinion on the submission by a citizen (LTL 483) on Social Security Coordination (2017). Available at: https://wayback.archive-it.org/12090/20200308120709/https:// ec.europa.eu/info/sites/info/files/vii5a_social_security_coordination.pdf

39. REFIT Platform: REFIT Platform Opinion on the submission by a citizen (LtL 242) on Identity and Travel Documents (2017). Available at: https://wayback.archive-it.org/12090/20200308121307/ https://ec.europa.eu/info/sites/info/files/xiii3aidentitytravel_documents.pdf

40. REFIT Platform: REFIT Platform Opinion on the submission by a member of the Stakeholder group on the European Citizens' initiative (2016). Available at: https://ec.europa.eu/info/sites/info/files/ opinion_european_citizen_initiative_final.pdf

41. REFIT Platform: REFIT Platform Opinion on the submission by a member of the Stakeholder group on the European Citizens' initiative (2016). Available at: https://wayback.archive-it.org/12090/ 20200308121646/https://ec.europa.eu/info/sites/info/files/opinion_european_citizen_initiative_final. pdf

42. REFIT Platform: REFIT Platform Opinion on the submission by a member of the REFIT Platform Stakeholder group (Ms Kavrakova) on the Citizenship Directive (2017). Available at: https://wayback.archive-it.org/12090/20200308121324/https://ec.europa.eu/info/sites/info/ files/xiii-10-a-social-security-coordination_en.pdf

43. REFIT Platform: REFIT Platform Opinion on the submissions XXII.4.a by the DIHK and XXII.4.b by a citizen on Stakeholder consultation mechanisms (2017). Available at: https://ec.europa.eu/info/ sites/info/files/xxii4ab_on_stakeholder_consultation_mechanisms.pdf

44. REFIT Platform: REFIT Platform Opinion on the submissions XXII.4.a by the DIHK and XXII.4.b by a citizen on Stakeholder consultation mechanisms (2017). Available at: https://wayback.archiveit.org/12090/20200308121740/https://ec.europa.eu/info/sites/info/files/xxii4ab_on_stakeholder_ consultation_mechanisms.pdf

45. Regulation (EU) 2019/788 of the European Parliament and of the Council of 17 April 2019 on the European citizens' initiative. Off. J. Eur. Union L 130/55 (2019). Available at: https://eur-lex.europa. eu/legal-content/EN/TXT/?qid=1558082143592\&uri=CELEX:32019R0788

46. Right2Water: Website. Available at: https://www.right2water.eu/

47. Stop Glyphosate: Website. Available at: https://stopglyphosate.org/

48. Stop Vivisection: Website. Available at: http://stopvivisection.eu/en

49. The ECI Campaign: ECI Help Desk. Available at: https://citizens-initiative.eu/help-desk/

50. Treaty on European Union. Off. J. Eur. Union C191/1 (1992), 8. Available at: https://europa.eu/ european-union/sites/europaeu/files/docs/body/treaty_on_european_union_en.pdf

Publisher's Note Springer Nature remains neutral with regard to jurisdictional claims in published maps and institutional affiliations. 